\title{
GTP mobilization of $\mathrm{Ca}^{2+}$ from the endoplasmic reticulum of islets
}

\author{
Comparison with myo-inositol 1,4,5-trisphosphate
}

Bryan A. WOLF, ${ }^{*} \ddagger$ Jon FLORHOLMEN, ${ }^{*}$ Jerry R. COLCA $\dagger$ and Michael L. MCDANIEL*

*Department of Pathology, Washington University School of Medicine, St. Louis, MO 63110, U.S.A., and †Division of Diabetes and Gastrointestinal Diseases, The Upjohn Company, Kalamazoo, MI 49009, U.S.A.

\begin{abstract}
The effect of the guanine nucleotide GTP on $\mathrm{Ca}^{2+}$ release from the endoplasmic reticulum of digitoninpermeabilized islets was investigated. Maximal and half-maximal $\mathrm{Ca}^{2+}$ release were observed at $5 \mu \mathrm{M}$ - and $2.5 \mu \mathrm{M}-\mathrm{GTP}$ respectively. GTP caused a rapid release of $\mathrm{Ca}^{2+}$ from the endoplasmic reticulum, which was complete within $1 \mathrm{~min}$. GTP-induced $\mathrm{Ca}^{2+}$ release was structurally specific and required the hydrolysis of GTP. The combination of maximal concentrations of GTP $(10 \mu \mathrm{M})$ and myo-inositol 1,4,5-trisphosphate $\left(\mathrm{IP}_{3}\right)(10 \mu \mathrm{M})$ resulted in an additive effect on $\mathrm{Ca}^{2+}$ release from the endoplasmic reticulum. GDP $(100 \mu \mathrm{M})$, which inhibits GTP-induced $\mathrm{Ca}^{2+}$ release, did not affect $\mathrm{IP}_{3}$-induced $\mathrm{Ca}^{2+}$ release. Furthermore, GTP-induced $\mathrm{Ca}^{2+}$ release was not independent on submicromolar free $\mathrm{Ca}^{2+}$ concentrations, unlike $\mathrm{IP}_{3}$-induced $\mathrm{Ca}^{2+}$ release. These observations suggest that mechanistically GTP-induced $\mathrm{Ca}^{2+}$ release is different from $\mathrm{IP}_{3}$-induced $\mathrm{Ca}^{2+}$ release from the endoplasmic reticulum.
\end{abstract}

\section{INTRODUCTION}

Changes in intracellular $\mathrm{Ca}^{2+}$ concentrations are recognized as having a major role in insulin secretion (Wollheim \& Sharp, 1981; Prentki \& Wollheim, 1984; Wollheim \& Pozzan, 1984; McDaniel et al., 1985; Hellman, 1985; Wollheim \& Biden, 1986). The endoplasmic reticulum has a prominent role in the regulation of intracellular $\mathrm{Ca}^{2+}$ concentrations in islet $\beta$-cells under basal and insulin-stimulatory conditions (for review see Turk et al., 1987). Our laboratory has described several biochemical mechanisms whch contribute to intracellular $\mathrm{Ca}^{2+}$ homoeostasis under physiological conditions: (1) a $\mathrm{Ca}^{2+}$-sequestering pump associated with a $\mathrm{Ca}^{2+}$-ATPase localized to the endoplasmic reticulum (Colca et al., 1982, 1983a,b); (2) a $\mathrm{Ca}^{2+}$-sequestering mechanism localized to the endoplasmic reticulum, which is regulated by glucose 6-phosphate and has been implicated in glucose-induced insulin release (Wolf et al., 1986c); and (3) $\mathrm{Ca}^{2+}$ mobilization or efflux from the endoplasmic reticulum (Wolf et al., 1985, 1986a,b,d). Although the precise molecular mechanisms are not known, we and others have shown that $\mathrm{IP}_{3}$, a proposed second messenger (Berridge \& Irvine, 1984), mobilizes $\mathrm{Ca}^{2+}$ from the endoplasmic reticulum of islet $\beta$-cells (Wolf et al., 1985, 1986a) and of insulinoma cell lines (Prentki et al., 1984; Biden et al., 1984; Joseph et al., 1984).

Several reports have shown that the guanine nucleotide GTP could induce $\mathrm{Ca}^{2+}$ release from rat liver microsomal fractions and from the endoplasmic reticulum of the NIE-115 neuronal cell line and the guinea-pig parotid gland (Dawson, 1985; Dawson et al., 1986; Gill et al., 1986; Ueda et al., 1986; Henne \& Söling, 1986). However, the relationship between GTP-induced and $\mathrm{IP}_{3}$-induced $\mathrm{Ca}^{2+}$ release from the endoplasmic reticulum is not clear
(Baker, 1986). We have examined the role of guanine nucleotides in $\mathrm{Ca}^{2+}$ mobilization from the endoplasmic reticulum of islet $\beta$-cells, using a characterized digitoninpermeabilized-islet model (Colca et al., 1985; Wolf et al., $1985,1986 a, b, c)$.

\section{EXPERIMENTAL}

\section{Materials}

Male Sprague-Dawley rats (180-200 g) were purchased from Sasco (O'Fallon, MO, U.S.A.). Collagenase (CLS IV) was obtained from Cooper Biomedical (Freehold, NJ, U.S.A.). ${ }^{45} \mathrm{CaCl}_{2}$ (sp. radioactivity $800 \mathrm{mCi} / \mathrm{mmol}$ ), ${ }^{3} \mathrm{H}_{2} \mathrm{O}$, Protosol and Aquasol were from New England Nuclear (Boston, MA, U.S.A.). $\left[\alpha^{-32}\right.$ P]GTP was from Amersham. GTP[S] (tetralithium salt) and GDP[S] (trilithium salt) were obtained from Sigma Chemical Co. (St. Louis, MO, U.S.A.). $\mathrm{IP}_{3}$ was generously given by Dr. William Sherman, Department of Psychiatry, Washington University School of Medicine, and was prepared as previously described (Wolf et al., 1985). All other chemicals were obtained from Sigma.

\section{Methods}

Islet isolation and permeabilization. Isolated pancreatic islets were obtained by collagenase digestion, followed by separation and purification on a discontinuous Ficoll gradient (McDaniel et al., 1983, 1984). Freshly isolated islets (2000-3000 per experiment) were then permeabilized with digitonin by incubation in a modified Hepes/Krebs buffer (25 mM-Hepes, pH 6.8, $115 \mathrm{~mm}-\mathrm{NaCl}, 24 \mathrm{~mm}-\mathrm{NaHCO}_{3}, \quad 5 \mathrm{~mm}-\mathrm{KCl}, \quad 1 \mathrm{~mm}-$ $\mathrm{MgCl}_{2}, 1 \mathrm{~mm}$-EGTA, $0.1 \%$ bovine plasma albumin) at $37{ }^{\circ} \mathrm{C}$ with $20 \mu \mathrm{g}$ of digitonin (Sigma) $/ \mathrm{ml}$ for $20 \mathrm{~min}$. Permeabilized islets were washed three times in Tris

Abbreviations used: $\mathrm{IP}_{3}$, myo-inositol 1,4,5-trisphosphate; GTP[S], guanosine $5^{\prime}$-[ $\gamma$-thio]triphosphate; GDP[S], guanosine $5^{\prime}$-[ $\beta$-thio]diphosphate.

$\ddagger$ To whom correspondence should be addressed. 
buffer $(50 \mathrm{~mm}$-Tris/HCl, pH 6.8, $100 \mathrm{~mm}-\mathrm{KCl}, 5 \mathrm{~mm}$ $\mathrm{MgCl}_{2}, 0.1 \%$ bovine plasma albumin) before use (Colca et al., 1985; Wolf et al., 1985, 1986a,b).

$\mathrm{Ca}^{2+}$ efflux in permeabilized islets. Permeabilized islets (30 per $1.5 \mathrm{ml}$ polyallomer Beckman Microfuge tube) were loaded for $30 \mathrm{~min}$ at room temperature with $5 \mu \mathrm{Ci}$ of ${ }^{45} \mathrm{Ca}^{2+}$ and $5 \mu \mathrm{Ci}$ of ${ }^{3} \mathrm{H}_{2} \mathrm{O}$ as a cell volume marker in $95 \mu \mathrm{l}$ of a Pipes buffer mimicking intracellular conditions (100 mm-Pipes, pH 7.0, $100 \mathrm{~mm}-\mathrm{KCl}, \quad 7 \mathrm{~mm}-\mathrm{MgCl}_{2}$, $5 \mathrm{~mm}$-ATP, $2.25 \mu \mathrm{g}$ of Ruthenium Red $/ \mathrm{ml}$ ). The free $\mathrm{Ca}^{2+}$ concentration of this buffer was set at $0.2 \mu \mathrm{M}$ by including EGTA at a concentration of $0.096-0.138 \mathrm{~mm}$, depending on the specific radioactivity of ${ }^{45} \mathrm{CaCl}_{2}$ (500-1000 $\mathrm{mCi} / \mathrm{mmol}$ ) as previously described (Wolf et al., 1986a). We have previously shown that a $\mathrm{Ca}^{2+}$ steady-state maintained by the endoplasmic reticulum is reached after a $30 \mathrm{~min}$ incubation (Wolf et al., 1985, $1986 a, b, c) . \mathrm{Ca}^{2+}$ efflux was then initiated by the addition of $5 \mu \mathrm{l}$ of the appropriate effluxing agent in $200 \mathrm{~mm}$-Pipes, $\mathrm{pH}$ 7.0. Tubes were also included which were incubated in parallel in the absence of ATP. $\mathrm{Ca}^{2+}$ efflux was stopped at the appropriate time by centrifugation ( $15 \mathrm{~s}$. $10000 \mathrm{~g}$ ). The supernatant of each tube was removed and the islet pellet was processed as previously described (Wolf et al., 1985, 1986a). Calculations were performed by computing the volume associated with ${ }^{45} \mathrm{Ca}^{2+}$ and subtracting the volume occupied by ${ }^{3} \mathrm{H}_{2} \mathrm{O}$, thus measuring the volume corresponding to the uptake of ${ }^{45} \mathrm{Ca}^{2+}$ by the islet. Non-ATP-dependent ${ }^{45} \mathrm{Ca}^{2+}$ uptake (which represents ${ }^{45} \mathrm{Ca}^{2+}$ binding to the plasma membrane and secretory granules) is then subtracted. Since Ruthenium Red is present to inhibit mitochondrial ATP-dependent ${ }^{45} \mathrm{Ca}^{2+}$ uptake (the other major ATP-dependent $\mathrm{Ca}^{2+}$ pool in islets) (McDaniel et al., 1985; Prentki \& Wollheim, 1984) and the free $\mathrm{Ca}^{2+}$ is maintained at $0.2 \mu \mathrm{M}$, the final result ( $\mathrm{pmol}$ of $\mathrm{Ca}^{2+} /$ islet) is a reflection of the ATP-dependent ${ }^{45} \mathrm{Ca}^{2+}$ content of the endoplasmic reticulum (Wolf et al., 1986a).

Other methods. GTP degradation was measured quantitatively by incubating 250 permeabilized islets with $\left[\alpha{ }^{32} \mathrm{P}\right] \mathrm{GTP}$ under conditions similar to those for GTP-induced $\mathrm{Ca}^{2+}$ efflux. Labelled guanine nucleotides were then extracted with $15 \%(\mathrm{w} / \mathrm{v})$ trichloroacetic acid, processed and analysed by anion-exchange h.p.l.c. as previously described (Turk et al., 1986). Free $\mathrm{Ca}^{2+}$ concentrations were maintained by including EGTA and verified with a $\mathrm{Ca}^{2+}$-specific electrode as previously described (Wolf et al., 1986a). The preparation of ATP stocks and Ruthenium Red has been described (Wolf $e t$ al., 1986a). Guanine nucleotides were dissolved in 200 mm-Pipes, $\mathrm{pH} 7.0$, and titrated to $\mathrm{pH} 7.0$ with $1 \mathrm{M}-\mathrm{KOH}$.

Statistical analysis. Data were analysed by one-way ANOVA, followed by multiple comparison between means with the least-significant-difference test. All experiments were performed at least three times in triplicate unless otherwise indicated.

\section{RESULTS}

The guanine nucleotide GTP mobilized $\mathrm{Ca}^{2+}$ from the endoplasmic reticulum of digitonin-permeabilized islets. Fig. 1 shows the GTP dose/response curve for $\mathrm{Ca}^{2+}$

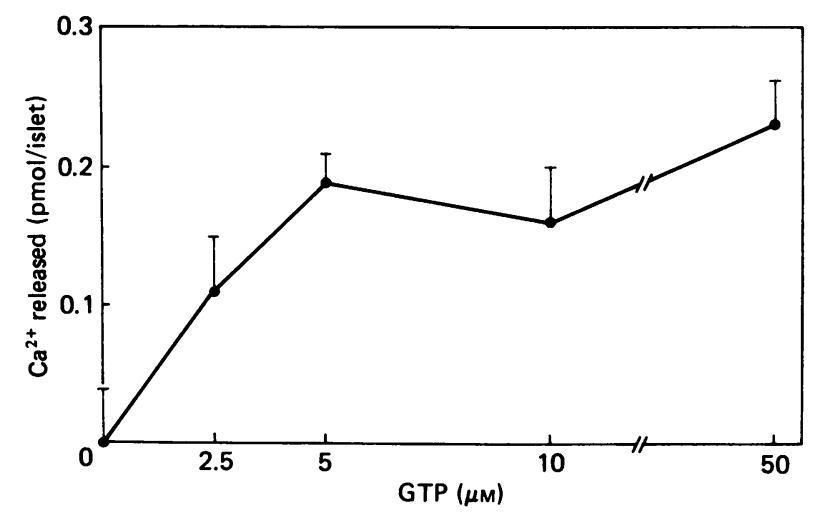

Fig. 1. Dose/response curve of GTP-induced $\mathrm{Ca}^{2+}$ release from the endoplasmic reticulum of digitonin-permeabilized islets

Permeabilized islets were loaded with ${ }^{45} \mathrm{Ca}^{2+}$ as described in the Experimental section. $\mathrm{Ca}^{2+}$ efflux from the endoplasmic reticulum was then measured after $10 \mathrm{~min}$ in the presence of GTP $(0-50 \mu \mathrm{M})$. Non-ATP-dependent $\mathrm{Ca}^{2+}$ content of the endoplasmic reticulum was subtracted for each condition. $\mathrm{Ca}^{2+}$ release is expressed as the ATPdependent $\mathrm{Ca}^{2+}$ content of the endoplasmic reticulum in the absence of GTP minus the ATP-dependent $\mathrm{Ca}^{2+}$ content of the endoplasmic reticulum in the presence of GTP. Control ATP-dependent $\mathrm{Ca}^{2+}$ content of the endoplasmic reticulum was $0.93 \pm 0.04 \mathrm{pmol} /$ islet. Results are shown as means \pm S.E.M. of $\mathrm{Ca}^{2+}$ released (pmol/islet) from the endoplasmic reticulum for 18-26 observations per each condition for three experiments.

release $(10 \mathrm{~min})$ from the endoplasmic reticulum. The non-ATP-dependent $\mathrm{Ca}^{2+}$ content of islets was not affected by GTP. Maximal and half-maximal $\mathrm{Ca}^{2+}$ release were observed at $5 \mu \mathrm{M}-(P<0.001)$ and $2.5 \mu \mathrm{M}-(P<0.05)$ GTP respectively. The time course of GTP-induced $\mathrm{Ca}^{2+}$ release from the endoplasmic reticulum is illustrated in Fig. 2. GTP $(10 \mu \mathrm{M})$ induced maximal $\mathrm{Ca}^{2+}$ release within $1 \mathrm{~min}(P<0.02)$, followed by progressive $\mathrm{Ca}^{2+}$ re-uptake over the next $20 \mathrm{~min}$.

The specificity of GTP-induced $\mathrm{Ca}^{2+}$ release from the endoplasmic reticulum was next examined (Table 1). The non-hydrolysable analogue of GTP, GTP[S], had no effect on $\mathrm{Ca}^{2+}$ release at 10 and $50 \mu \mathrm{M}$. GDP at $10 \mu \mathrm{M}$ did not elicit any $\mathrm{Ca}^{2+}$ release from the endoplasmic reticulum. However, $50 \mu \mathrm{M}$-GDP mobilized $\mathrm{Ca}^{2+}$ as effectively as did GTP $(P<0.001)$. This latter effect can be ascribed to phosphorylation of GDP by a nucleoside kinase in the presence of ATP to form GTP (Gill et al., 1986). Nucleoside kinase is effectively inhibited by $100 \mu \mathrm{M}-\mathrm{GDP}$. $\mathrm{Ca}^{2+}$ release was not observed in the presence of $100 \mu \mathrm{M}$-GDP $(P<0.001)$. Furthermore, GDP[S], a GDP analogue which is neither hydrolysed nor phosphorylated, and GMP did not mobilize $\mathbf{C a}^{2+}$ from the endoplasmic reticulum. Thus GTP-induced $\mathrm{Ca}^{2+}$ release is highly specific. The fact that GTP[S] did not induce any $\mathrm{Ca}^{2+}$ release from the endoplasmic reticulum indicated that $\mathrm{Ca}^{2+}$ release was dependent on GTP being either hydrolysed or providing a high-energy phosphate group in a phosphorylation reaction. Interestingly, the combination of GTP with GDP or GDP[S] inhibited GTP-induced $\mathrm{Ca}^{2+}$ release from the endoplasmic reticulum (Table 1), suggesting that hydrolysis of 


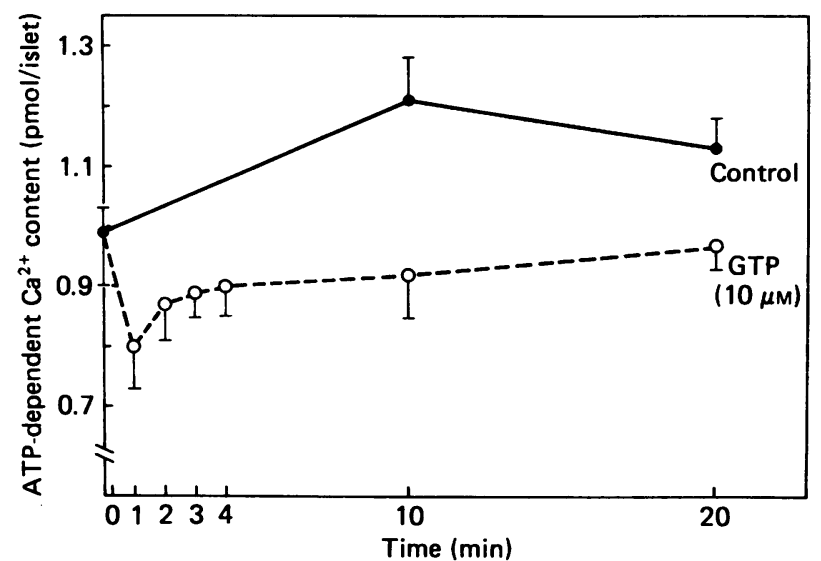

Fig. 2. Time course of GTP-induced $\mathrm{Ca}^{2+}$ release from the endoplasmic reticulum of digitonin-permeabilized islets

Permeabilized islets were loaded with ${ }^{45} \mathrm{Ca}^{2+}$ as described in the Experimental section. $\mathrm{Ca}^{2+}$ efflux was initiated by the addition of GTP $(10 \mu \mathrm{M} ; O)$ or not (control; $O)$, and the ATP-dependent $\mathrm{Ca}^{2+}$ content of the endoplasmic reticulum was determined at $0,1,2,3,4,10$ and $20 \mathrm{~min}$ after initiation of $\mathrm{Ca}^{2+}$ efflux. Non-ATP-dependent $\mathrm{Ca}^{2+}$ content was subtracted from the data. Results are shown as means \pm S.E.M. of ATP-dependent $\mathrm{Ca}^{2+}$ content (pmol/ islet) of the endoplasmic reticulum from 12-18 observations per each condition for three experiments.

GTP is required for GTP-induced $\mathrm{Ca}^{2+}$ release from the endoplasmic reticulum.

Reports in the literature have indicated that GTP enhances $\mathrm{IP}_{3}$-induced $\mathrm{Ca}^{2+}$ release (Dawson, 1985). Others have suggested that GTP- and $\mathrm{IP}_{3}$ - induced $\mathrm{Ca}^{2+}$ release are not related (Gill et al., 1986; Ueda et al., 1986; Henne \& Söling, 1986). We have compared $\mathrm{IP}_{3}$-induced and GTP-induced $\mathrm{Ca}^{2+}$ release from the endoplasmic reticulum of islets. Fig. 3 indicates that the combination of GTP $(10 \mu \mathrm{M})$ and $\mathrm{IP}_{3}(10 \mu \mathrm{M})$ was completely additive for $\mathrm{Ca}^{2+}$ release $\left(0.53 \pm 0.04 \mathrm{pmol}\right.$ of $\mathrm{Ca}^{2+}$ released/islet, $P<0.001$ versus control) as compared with either GTP alone $\left(0.23 \pm 0.07 \mathrm{pmol}\right.$ of $\mathrm{Ca}^{2+}$ released/islet, $P<0.05$ versus control) or $\mathrm{IP}_{3}$ alone $\left(0.32 \pm 0.06 \mathrm{pmol}\right.$ of $\mathrm{Ca}^{2+}$ released/islet, $P<0.002$ versus control). This observation suggests that different mechanisms are involved in $\mathrm{IP}_{3}$ - and GTP-induced $\mathrm{Ca}^{2+}$ release. Furthermore, GDP $(100 \mu \mathrm{M})$ at a concentration which inhibits GTP-induced $\mathrm{Ca}^{2+}$ release did not affect $\mathrm{IP}_{3}$-induced $\mathrm{Ca}^{2+}$ release from the endoplasmic reticulum (Table 1). GTP-induced $\mathrm{Ca}^{2+}$ release from the endoplasmic reticulum was also examined at a free $\mathrm{Ca}^{2+}$ concentration of $40 \mu \mathrm{M}$, since previous studies have demonstrated that $\mathrm{IP}_{3}$ does not cause any $\mathrm{Ca}^{2+}$ release from the endoplasmic reticulum at a free $\mathrm{Ca}^{2+}$ concentration of $40 \mu \mathrm{M}$ (Wolf et al., 1985, 1986a). At a free $\mathrm{Ca}^{2+}$ concentration of $40 \mu \mathrm{M}$, GTP $(5 \mu \mathrm{M})$ mobilized $21.7 \pm 5.2 \%$ of the ATP-dependent $\mathrm{Ca}^{2+}$ content of the endoplasmic reticulum $(P<0.002$ versus control), whereas the $\mathrm{Ca}^{2+}$ ionophore $\mathrm{A} 23187$ $(2 \mu \mathrm{M})$ released $54.5 \pm 5.6 \%(P<0.001$ versus control $)$.

The effect of GTP on $\mathrm{Ca}^{2+}$ release from the endoplasmic reticulum cannot be explained by inhibition of the ATP-dependent $\mathrm{Ca}^{2+}$-transport pump of the endoplasmic reticulum, since GTP $(10 \mu \mathrm{M})$ did not affect the initial rate of $\mathrm{Ca}^{2+}$ uptake during the first $1.5 \mathrm{~min}$ (results not shown). Studies performed with $\left[\alpha^{-32}\right.$ P]GTP
Table 1. Specificity of GTP-induced $\mathrm{Ca}^{2+}$ release from the endoplasmic reticulum of digitonin-permeabilized islets

$\mathrm{Ca}^{2+}$ release (pmol/islet) was measured as described in the Experimental section in the presence of guanine nucleotides. Control ATP-dependent $\mathrm{Ca}^{2+}$ content of the endoplasmic reticulum was $1.11 \pm 0.04 \mathrm{pmol} /$ islet.

\begin{tabular}{lcc}
\hline Agent & Concn. $(\mu \mathrm{M})$ & $\mathrm{Ca}^{2+}$ released (pmol/islet) \\
\hline GTP & 10 & $0.35 \pm 0.04^{* *}(32)$ \\
& 50 & $0.34 \pm 0.04^{* *}(18)$ \\
GTP[S] & 10 & $0.05 \pm 0.07(18)$ \\
& 50 & $0.07 \pm 0.05(18)$ \\
GDP & 10 & $0.12 \pm 0.07(18)$ \\
& 50 & $0.37 \pm 0.05^{* *}(18)$ \\
GDP[S] & 100 & $0.08 \pm 0.06 \quad(18)$ \\
& 10 & $0.12 \pm 0.06(14)$ \\
GMP & 50 & $0.04 \pm 0.07(17)$ \\
& 10 & $0.03 \pm 0.06(18)$ \\
GTP+GDP & 50 & $0.07 \pm 0.06(18)$ \\
GTP+GDP[S] & $10+100$ & $0.10 \pm 0.04(18)$ \\
IP & $10+50$ & $0.12 \pm 0.05(17)$ \\
IP ${ }_{3}+$ GDP & 10 & $0.32 \pm 0.04^{*}(6)$ \\
& $10+100$ & $0.33 \pm 0.04^{* *}(12)$ \\
$* P<0.005 ; * * P<0.001$. & \\
\hline
\end{tabular}

$(10 \mu \mathrm{M})$ indicated that, during a $10 \mathrm{~min}$ incubation period, $80 \%$ of the GTP was not degraded (results not shown). Furthermore, those studies showed that, in the presence of ATP, there was significant phosphorylation of GDP to GTP.

\section{DISCUSSION}

We have used the digitonin-permeabilized islet model to assess the effect of GTP on $\mathrm{Ca}^{2+}$ fluxes maintained by the endoplasmic reticulum. Previous work from our laboratory has demonstrated that $\mathrm{Ca}^{2+}$ efflux from the endoplasmic reticulum of islets can be measured with the digitionin-permeabilized-islet model (Wolf et al., 1985, $1986 a, b, c)$. GTP caused rapid release of $\mathrm{Ca}^{2+}$ from the endoplasmic reticulum when measured under conditions which mimic intracellular conditions, thus providing to our knowledge the first demonstration of an effect of GTP on $\mathrm{Ca}^{2+}$ release from the endoplasic reticulum of an endocrine cell. GTP-induced $\mathrm{Ca}^{2+}$ release from the endoplasmic reticulum was structurally specific and dose-dependent. Furthermore, this effect was observed in the absence of any added poly(ethylene glycol). In previous studies, the latter was required to observe GTP-induced $\mathrm{Ca}^{2+}$ release. These observations in the endoplasmic reticulum of islets confirm and extend previously reports of GTP-induced $\mathrm{Ca}^{2+}$ release from rat liver microsomal fractions, the endoplasmic reticulum of NIE-115 neuronal cells and the guinea-pig parotid gland (Dawson, 1985; Dawson et al., 1986; Gill et al., 1986; Ueda et al., 1986; Henne \& Söling, 1986).

$\mathrm{IP}_{3}$ is recognized as a second messenger in numerous cells (Berridge \& Irvine, 1984) and has been proposed to be involved in glucose-induced and carbamoylcholine- 


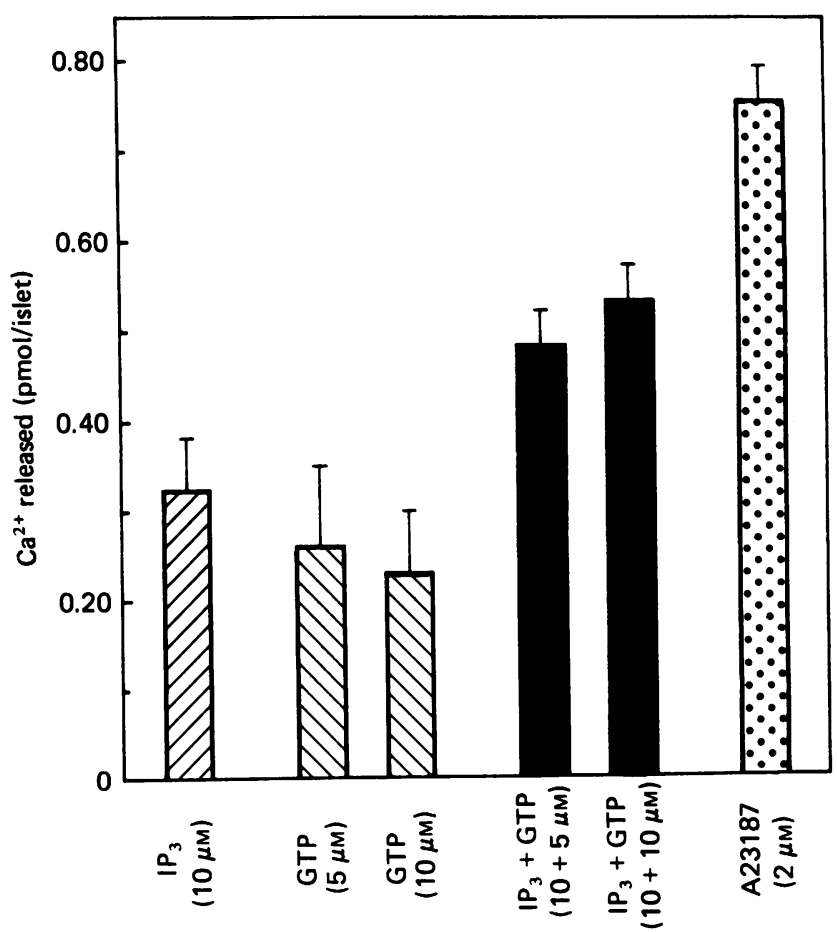

Fig. 3. Comparison of $\mathrm{IP}_{3}$ - and/or GTP-induced $\mathrm{Ca}^{2+}$ release from the endoplasmic reticulum of digitonin-permeabilized islets

Permeabilized islets were loaded with ${ }^{45} \mathrm{Ca}^{2+}$ as described in the Experimental section. $\mathrm{Ca}^{2+}$ efflux was initiated by the addition of $\mathrm{IP}_{3}(10 \mu \mathrm{M} ; \bigotimes)$, GTP $(5$ and $10 \mu \mathrm{M} ; \mathbb{\nabla})$, $\mathrm{IP}_{3}+$ GTP $(10+5,10+10 \mu \mathrm{M}$ respectively; $\square)$ and A23187 (2 $\mu \mathrm{M}$; 图). $\mathrm{Ca}^{2+}$ efflux was carried out for $10 \mathrm{~min}$. Non-ATP-dependent $\mathrm{Ca}^{2+}$ content was subtracted from the data. Control ATP-dependent $\mathrm{Ca}^{2+}$ content of the endoplasmic reticulum was $1.00 \pm 0.10 \mathrm{pmol} /$ islet. $\mathrm{Ca}^{2+}$ release was calculated as in Fig. 1 and is expressed as the mean \pm S.E.M. (pmol/islet) from 12 observations per each condition for two experiments.

induced insulin secretion (for review see Turk et al., 1987; Wolf et al., 1985; Wollheim \& Biden, 1986; Prentki \& Wollheim, 1984). Dawson and co-workers have proposed, on the basis of studies with a rat liver microsomal fraction, that $\mathrm{IP}_{3}$-induced $\mathrm{Ca}^{2+}$ release from liver endoplasmic reticulum is mediated by GTP-phosphorylation of a protein which binds to microsomal membranes (Dawson, 1985; Dawson et al., 1986). Studies by Gill and co-workers have suggested in studies performed with the NIE-115 neuronal cell line that GTP-induced $\mathrm{Ca}^{2+}$ release is probably related to $\mathrm{IP}_{3}$-induced $\mathrm{Ca}^{2+}$ release (Ueda et al., 1986). However, Henne \& Söling (1986) have suggested that GTP-induced $\mathrm{Ca}^{2+}$ release is independent of $\mathrm{IP}_{3}$-induced $\mathrm{Ca}^{2+}$ release in microsomal fractions of rat liver and guinea-pig parotid gland. Our studies in islet endoplasmic reticulum indicate that GTP-induced $\mathrm{Ca}^{2+}$ release is probably independent of $\mathrm{IP}_{3}$-induced $\mathrm{Ca}^{2+}$ release, since the combination of maximal doses of $\mathrm{IP}_{3}$ and GTP elicits precisely additive $\mathrm{Ca}^{2+}$ efflux from the endoplasmic reticulum, suggesting that different mechanisms of action are involved (Fig. 3). Furthermore, in the presence of a concentration of GDP which totally abolishes GTP-induced $\mathrm{Ca}^{2+}$ release, $\mathrm{IP}_{3}$-induced $\mathrm{Ca}^{2+}$ release is not affected. Finally, we have previously shown (Wolf et al., 1985, 1986a) that $\mathrm{IP}_{3}$-induced $\mathrm{Ca}^{2+}$ release from the endoplasmic reticulum of islets is only observed at submicromolar free $\mathrm{Ca}^{2+}$ concentrations. GTP-induced $\mathrm{Ca}^{2+}$ release from the endoplasmic reticulum was independent of the free $\mathrm{Ca}^{2+}$ concentration, however. These various lines of evidence indicate that GTP- and $\mathrm{IP}_{3}$-induced $\mathrm{Ca}^{2+}$ release occur through different mechanisms.

The mechanism of GTP-induced $\mathrm{Ca}^{2+}$ release from the endoplasmic reticulum of islets is not clear, although GTP hydrolysis seems important (Gill et al., 1986). The physiological significance of this observation and its relationship to glucose-induced insulin secretion remain unknown, since very little is known about GTP concentrations in islets (Hedeskov, 1980).

In conclusion, we have shown that GTP mobilizes $\mathrm{Ca}^{2+}$ from the endoplasmic reticulum of islets and that this effect is mechanistically different from $\mathrm{IP}_{3}$-induced $\mathrm{Ca}^{2+}$ release.

We thank Connie A. Marshall, C. Joan Fink and W. Tom Stump for excellent technical assistance, as well as Jennifer Ferrell for preparation of the manuscript.

\section{REFERENCES}

Baker, P. F. (1986) Nature (London) 320, 395

Berridge, M. J. \& Irvine, R. F. (1984) Nature (London) 312, 315-321

Biden, T. J., Prentki, M., Irvine, R. F., Berridge, M. J. \& Wollheim, C. B. (1984) Biochem. J. 223, 467-473

Colca, J. R., McDonald, J. M., Kotagal, N., Patke, C., Fink, C. J., Greider, M. H., Lacy, P. E. \& McDaniel, M. L. (1982) J. Biol. Chem. 257, 7223-7228

Colca, J. R., Kotagal, N., Lacy, P. E. \& McDaniel, M. L. (1983a) Biochem. J. 212, 113-121

Colca, J. R., Kotagal, N., Lacy, P. E. \& McDaniel, M. L. (1983b) Biochim. Biophys. Acta 729, 176-184

Colca, J. R., Wolf, B. A., Comens, P. G. \& McDaniel, M. L. (1985) Biochem. J. 228, 529-536

Dawson, A. P. (1985) FEBS Lett. 185, 147-150

Dawson, A. P., Comerford, J. G. \& Fulton, D. V. (1986) Biochem. J. 234, 311-315

Gill, D. L., Ueda, T., Chueh, S.-H. \& Noel, M. W. (1986) Nature (London) 320, 461-464

Hedeskov, C. J. (1980) Physiol. Rev. 60, 442-509

Hellman, B. (1985) Diabetologia 28, 494-501

Henne, V. \& Söling, H.-D. (1986) FEBS Lett. 202, 267-273

Joseph, S. K., Williams, R. J., Corkey, B. E., Matschinsky, F. M. \& Williamson, J. R. (1984) J. Biol. Chem. 259, 12952-12955

McDaniel, M. L., Colca, J. R., Kotagal, N. \& Lacy, P. E. (1983) Methods Enzymol. 98, 182-200

McDaniel, M. L., Colca, J. R. \& Kotagal, N. (1984) in Methods in Diabetes Research (Larner, J. \& Pohl, S., eds.), vol. 1, part A, pp. 153-166, John Wiley and Sons, New York

McDaniel, M. L., Colca, J. R., Kotagal, N. \& Lacy, P. E. (1985) in The Diabetic Pancreas (Volk, B. W. \& Arquilla, E. R., eds.), pp. 213-231, Plenum Press, New York

Prentki, M. \& Wollheim, C. B. (1984) Experientia 40, 1052-1060

Prentki, M., Biden, T. J., Janjic, D., Irvine, R. F., Berridge, M. J. \& Wollheim, C. B. (1984) Nature (London) 309, $562-564$

Turk, J., Wolf, B. A. \& McDaniel, M. L. (1986) Biochem J. 237, 259-263 
Turk, J., Wolf, B. A. \& McDaniel, M. L. (1987) Prog. Lipid Res., in the press

Ueda, T., Chueh, S.-H., Noel, M. W. \& Gill, D. L. (1986) J. Biol. Chem. 261, 3184-3192

Wolf, B. A., Comens, P. G., Ackermann, K. E., Sherman, W. R. \& McDaniel, M. L. (1985) Biochem. J. 227, 965-969

Wolf, B. A., Turk, J., Sherman, W. R. \& McDaniel, M. L. (1986a) J. Biol. Chem. 261, 3501-3509

Wolf, B. A., Turk, J., Comens, P. G., Sherman, W. R. \& McDaniel, M. L. (1986b) Ann. N.Y. Acad. Sci., in the press
Wolf, B. A., Colca, J. R., Comens, P. G., Turk, J. \& McDaniel, M. L. (1986c) J. Biol. Chem. 261, 16284-16287

Wolf, B. A., Colca, J. R. \& McDaniel, M. L. (1986d) Biochem. Biophys. Res. Commun. 141, 418-425

Wollheim, C. B. \& Biden, T. J. (1986) J. Biol. Chem. 261, 8314-8319

Wollheim, C. B. \& Pozzan, T. (1984) J. Biol. Chem. 259, $2262-2267$

Wollheim, C. B. \& Sharp, G. W. P. (1981) Physiol. Rev. 61, 914-973

Received 28 October 1986/25 November 1986; accepted 1 December 1986 